\title{
NEONATAL HEARING SCREENING IN INTENSIVE CARE UNITS
}

\section{Vasilios F. Chalkiadakis, loannis Geramas, Pavlos Marangoudakis, Dimitrios Kandiloros, Petros Vlastarakos, Thomas P. Nikolopoulos}

$2^{\text {nd }}$ University ENT Department, Attiko Hospital, Athens, Greece

Corresponding author: Vasilios Chalkiadakis, Mykonou 1, PO 17342, Agios Dimitrios, Athens, Greece, Tel. +306974357069, e-mail: chalkiadakis.v@gmail.com

\begin{abstract}
Background: Diagnosis of neonatal hearing impairment depends on universal hearing screening programs (otoacoustic emissions, OAEs, and/or auditory brainstem responses, ABRs). The aim of this study is to determine the prevalence of hearing impairment among high-risk newborns and identify the risk factors involved.

Materials and methods: This is a prospective cohort study on 173 newborns hospitalized in a neonatal intensive care unit (NICU) with one or more risk factors for hearing impairment. Both TEOAEs and a-ABRs were performed a few days before discharge.

Results: On examination with TEOAEs, 170 neonates eventually passed the test and 3 failed ( 1 bilaterally and 2 unilaterally). All neonates were also examined with a-ABR, and 10 failed the test, 7 of which passed TEOAE and were diagnosed as having possible auditory neuropathy spectrum disease (ANSD). The remaining 3 infants who failed both tests were diagnosed as having possible hearing loss (HL). From the risk factors, only TORCH infections were clearly related to the likelihood of hearing impairment, either ANSD or HL $(p=0.004)$. The need for mechanical ventilation was also significantly higher in newborns with possible HL, compared to those with normal results $(66.7 \% v s .18 .4 \%, p=0.03)$.
\end{abstract}

Conclusions: Combined TEOAE/ABR is the gold standard examination for NICU infants due to the increased incidence of $\mathrm{HL}$, especially ANSD, in this high-risk population.

Keywords: neonatal hearing screening • otoacoustic emissions $\bullet$ ABR $\bullet$ auditory neuropathy

\section{CRIBADO NEONATAL REALIZADO EN LAS UNIDADES DE CUIDADOS INTENSIVOS}

\section{Resumen}

Introducción: Diagnóstico de hipoacusia neonatal depende de los programas universales de cribado (las otoemisiones acústicas OEA o/y los potenciales auditivos evocados ABR). El objetivo de la prueba fue analizar los casos de hipoacusia en los recién nacios de riesgo y la identificación de los factores de riesgo.

Materiales y métodos: Se estudiaron 173 recién nacidos hospitalizados en la unidad de cuidados intensivos neonatales (UCIN), en los que aparece por lo menos un factor de riesgo que puede provocar la hipoacusia. Unos días antes de dar de alta del hospital se realizó la prueba de otoemisiones acústicas evocadas transitorias (TEOAE) y la prueba de potenciales auditivos evocados (a-ABR).

Resultados: 170 recién nacidos obtuvieron resultados positivos de la prueba TEOAE, tres de ellos - resultados negativos (en uno de los pacientes se detectó hipoacusia bilateral, en dos de ellos - unilateral). Todos los recién nacidos pasaron también por la prueba ABR. 10 de ellos obtuvieron resultados negativos, de los cuales 7 obtuvo resultados positivos de la prueba TEOAE, por lo que se sospechaba que presentan casos de neuropatía auditiva (ANSD). En cambio, en los tres recién nacidos restantes se sospechaba hipoacusia (HL). De los factores de riesgo, solamente las infecciones del grupo TORCH estaban evidentemente relacionadas con la probabilidad de hipoacusia - ANSD o HL ( $\mathrm{p}=0.004)$. La necesidad de utilizar ventilación mecánica aparecía con mayor frecuencia en los recién nacidos sospechados de hipoacusia que en el caso do los recién nacidos que obtuvieron resultados positivos (entre $66,7 \%$ y $18,4 \%, \mathrm{p}=0.03$ ).

Conclusiones: Las pruebas TEOAE y ABR se suelen realizar juntas en caso de los recién nacidos hospitalizados en las unidades de cuidados intensivos. Eso se debe al aumento del número de los casos de hipoacusia, especialmente ANSD en el grupo de alto riesgo.

Palabras clave: cribado neonatal $\bullet$ otoemisiones acústicas $\bullet$ ABR $\bullet$ neuropatía auditiva 


\section{СКРИНИНГОВЫЕ ИССЛЕДОВАНИЯ НОВОРОЖДЕННЫХ В ОТДЕЛЕНИЯХ ИНТЕНСИВНОЙ ТЕРАПИИ}

\section{Изложение}

Введение: Диагностика нарушений слуха у новорожденных зависит от всеобщих скрининг-программ (отоакустические эмиссии OAEs или/и слуховые вызванные потенциалы ABRs). Целью исследования являлся анализ нарушений слуха у новорожденных группы риска и идентификация опасных факторов.

Материал и методы: Потенциальное исследование группы 173 новорожденных, госпитализированных в отделении интенсивной терапии (NICU), у которых есть по крайней мере один фактор риска, влияющий на возникновение нарушений слуха. За несколько дней до выписки из больницы проведены исследования кратковременно вызванных отоакустических эмиссий (TEOAЕ) и тест автоматической детекции слуховых потенциалов (a-ABR).

Результаты: У 170 новорожденных получены положительные, а у троих - отрицательные результаты обследования TEOAE, (у одного пациента обнаружена двусторонняя тугоухость, у двоих - одностороняя). Все новорожденные были также подвергнуты обследованию ABR. У десяти новорожденных были получены отрицательные результаты. У семи из них получены положительные результаты обследования ТЕОАЕ с подозрением на наличие слуховой нейропатии (ANSD). У остальных же троих новорожденных подозревалась тугоухость (HL). Только заражения группы TORCH из факторов риска были четко связаны с вероятностью наличия слуховых нарушений - ANSD и HL (p=0,004). Необходимость механической вентиляции была значительно выше у новорожденных с подозрением на тугоухость в сравнении с пациентами, результаты которых были в норме (между $66,7 \%$ и $18,4 \%, \mathrm{p}=0,03)$.

Итоги: Исследования TEOAЕ и ABR - это сочетание, которое стандартно используется у новорожденных, пребывающих в отделениях интенсивной терапии. Причиной является рост наличия тугоухости, особенно ANSD в группе высокого риска.

Ключевые слова: скрининговые исследования новорожденных • отоакустические эмиссии • ABR • слуховая нейропатия

\section{BADANIA PRZESIEWOWE U NOWORODKÓW NA ODDZIAŁACH INTENSYWNEJ TERAPII}

\section{Streszczenie}

Wprowadzenie: Diagnostyka zaburzeń słuchu u noworodków jest zależna od powszechnych programów badań przesiewowych (otoemisje akustyczne OAEs lub/i słuchowe potencjały wywołane ABRs). Celem badania była analiza występowania zaburzeń słuchu u noworodków z grupy ryzyka oraz identyfikacja czynników zagrażających.

Materiał i metody: Potencjalne badanie na grupie 173 noworodków hospitalizowanych na oddziale intensywnej terapii (NICU), u których występuje przynajmniej jeden czynnik ryzyka wpływający na zaburzenie słuchu. Na kilka dni przed wypisem ze szpitala przeprowadzono badanie emisji otoakustycznych wywołanych krótkimi bodźcami (TEOAE) oraz test automatycznej detekcji potencjałów słuchowych (a-ABR).

Wyniki: 170 noworodków uzyskało pozytywny wynik badania TEOAE, a 3 - negatywny (u jednego pacjenta wykryto niedosłuch obustronny, a u dwóch jednostronny). Wszystkie noworodki poddane zostały także badaniu ABR. 10 uzyskało wynik negatywny. $7 \mathrm{z}$ nich uzyskało wynik pozytywny badania TEOAE, podejrzewając u nich wystąpienie neuropatii słuchowej (ANSD). Natomiast u pozostałej trójki noworodków podejrzewano niedosłuch (HL). Z czynników ryzyka, wyłącznie zakażenia z grupy TORCH były wyraźnie związane z prawdopodobieństwem wystąpienia zaburzeń słuchu - ANSD lub HL ( $\mathrm{p}=0,004)$. Potrzeba mechanicznej wentylacji była znacznie większa u noworodków z podejrzeniem niedosłuchu w porównaniu z pacjentami, których wyniki były w normie (pomiędzy $66,7 \%$ a $18,4 \%, p=0,03$ ).

Wnioski: Badania TEOAE i ABR są połączeniem stosowanym standardowo w przypadku noworodków przebywających na oddziałach intensywnej terapii. Powodem jest wzrost występowania niedosłuchu, szczególnie ANSD w grupie wysokiego ryzyka.

Słowa kluczowe: badania przesiewowe u noworodków • otoemisje akustyczne • ABR • neuropatia słuchowa 


\section{Background}

Good spoken language development in infants requires normal hearing ability. It is well known that an undiagnosed hearing loss, or even a delayed diagnosis, has multiple adverse effects later in life. Early identification means diagnosis of hearing impairment within the first 6 months of life. Early diagnosis combined with primary initiation of intervention services (by the end of the first year of life) will provide significant benefits in terms of vocabulary, general language ability, academic progress, and social and emotional development [1-3]. For this reason, in 1994, the Joint Committee on Infant Hearing (JCIH) stated that all neonates with hearing impairment should be identified before 3 months of age. Intervention, including hearing aids and cochlear implants, should be provided as early as possible following the confirmation of diagnosis [4].

Hearing impairment is a frequent disorder in neonates, more prevalent than other entities including phenylketonuria or hypothyroidism [5]. Currently, hearing loss is present in 1-3 per 1000 live births, and rises to 2-4 per 100 newborns in neonatal intensive care unit (NICU) populations. Nowadays, the JCIH has set principles and guidelines for early hearing detection and intervention, and universal neonatal hearing screening programs have been established in many countries [6]. These programs are based mainly on transient evoked otoacoustic emissions (TEOAEs) and/or auditory brainstem responses (ABRs). The presence of normal TEOAEs is indicative of normally functioning outer hair cells. On the other hand, the ABR relies on the synchronous discharge of neural units in the auditory pathways (the $8^{\text {th }}$ nerve and the brainstem).

Regarding neonates in the NICU, the gold standard is the combination of both TEOAEs and ABRs, as it is able to diagnose auditory neuropathy [7]. This term has been used to describe disorders characterized by normal outer hair function and dyssychrony or malfunction in the pathway between the inner hair cells and the brainstem. During the Consensus Conference on Auditory Neuropathy/Dys-synchrony in Como, Italy in 2008, this terminology was altered to Auditory Neuropathy Spectrum Disorder (ANSD) [8]. The site of injury in neonates suffering from this condition has not been clearly defined, and the disorder may range from auditory dyssynchrony to auditory nerve neuropathy. These patients usually present with difficulties in word discrimination that are disproportional to their hearing loss. It has been estimated that the prevalence of ANSD in NICU infants is approximately $2 \%$. Although the etiology remains unclear, ANSD has been associated with genetic and other neonatal risk factors. These perinatal risk indicators include not only syndromes associated with hearing impairment, but also familiar hearing loss, mechanical ventilation ( $>5$ days), craniofacial anomalies, premature birth (gestational age $<32$ weeks), low birth weight $(<1500 \mathrm{~g})$, severe birth asphyxia (Apgar $<7$ at $5 \mathrm{~min}$ ), TORCH infections (toxoplasmosis, other, rubella, cytomegalovirus, herpes), ototoxical medication, neurological disorders, and hyperbilirubinemia ( $>17 \mathrm{mg} / \mathrm{dL})$ [9].

All neonates born in our hospital are examined by TEOAEs as part of a routine screening test. However, in neonates hospitalized in the NICU, the assessment includes both TEOAEs and ABRs. The aim of the present study is to determine the prevalence of hearing loss, including ANSD, among newborns hospitalized in the NICU and identify the potential risk factors involved.

\section{Material and methods}

This study is a prospective cohort study on neonates hospitalized in the NICU of our hospital. All infants were screened by using a protocol that included TEOAEs and automated $\mathrm{ABR}$ (a-ABR). Neonates who had one or more of the following risk factors for hearing loss were included in the study:

1. Family history of hereditary childhood sensorineural hearing loss.

2. Mechanical ventilation lasting 5 days or longer.

3. Ototoxic medication (aminoglycosides, loop diuretics, etc.).

4. Hyperbilirunaemia more than $17 \mathrm{mg} / \mathrm{dL}$.

5. Congenital perinatal TORCH infection.

6. Craniofacial anomalies.

7. Stigmata or other findings associated with syndromes known to include a sensorineural and/or conductive hearing loss.

8. Prematurity (gestational age less than 32 weeks).

9. Birth weight less than $1500 \mathrm{~g}$.

10.Postnatal asphyxia (Apgar score $0-4$ at $1 \mathrm{~min} ; 0-6$ at 5 $\min )$.

11.Neurological disorders (convulsions, meningitis, endocranial hemorrhage, head trauma, hydrocephaly).

12.Post-genital infections.

Otolaryngological examination with otoscopy was performed on all newborns in order to determine the condition of the external auditory canal and the tympanic membrane. TEOAEs and a-ABR testing were performed during the infant's natural sleep or in a state of quiet rest. Sedation was not used. All tests were performed in a soundproof room, by the same staff. The initial examination was performed a few days before discharge from the hospital. All TEOAEs and a-ABR testing was performed by the Accuscreen device (Madsen-GN Otometrics, Taastrup, Denmark), a rechargeable handheld screening device that can perform both tests. The stimulus level with TEOAE is $70-84 \mathrm{~dB}$ SPL ( $45-60 \mathrm{~dB} \mathrm{HL}$ ), and the frequency range is $1.5-4.5 \mathrm{kHz}$. The available a-ABR levels are 35,40 , and $45 \mathrm{~dB}$. Different disposable soft probe tips were used according to the size of the external auditory canal. After adequate preparation of the skin, recording electrodes were attached to the upper forehead (recording electrode), ipsilateral mastoid process (reference electrode), and contralateral mastoid process (ground electrode). The presence of TEOAE/a-ABR was a PASS, whereas absence was a REFER. Neonates who failed were re-examined 48 hours later. In case the results were still REFER, parents were informed prior to hospital discharge and neonates were referred to the audiology department for full evaluation.

The scientific/ethical committee of our hospital approved the study. The investigation conformed to the principles of the Declaration of Helsinki.

Statistical analysis was performed using the SPSS 17.0 statistical software package (SPSS Inc., Chicago, Illinois, 


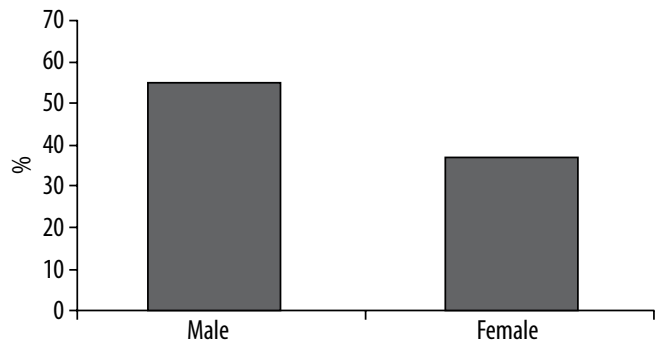

Figure 1. Proportion of male and female infants loss. There was a clear difference in male/female balance, with 107 males and 66 females, as depicted at Figure 1. Ototoxic medication was the most frequent risk factor (54.9\%), followed by hyperbilirubinaemia (26\%), prematurity (22\%), mechanical ventilation (19.1\%), low birth weight (16.8\%), and post-genital infections (15.6\%). Neurological disorders, TORCH infections, low Apgar score at $5 \mathrm{~min}$, craniofacial abnormalities, and family history of childhood deafness were less frequent. No infant presented with congenital anomalies or syndromes associated with hearing impairment (Figure 2).

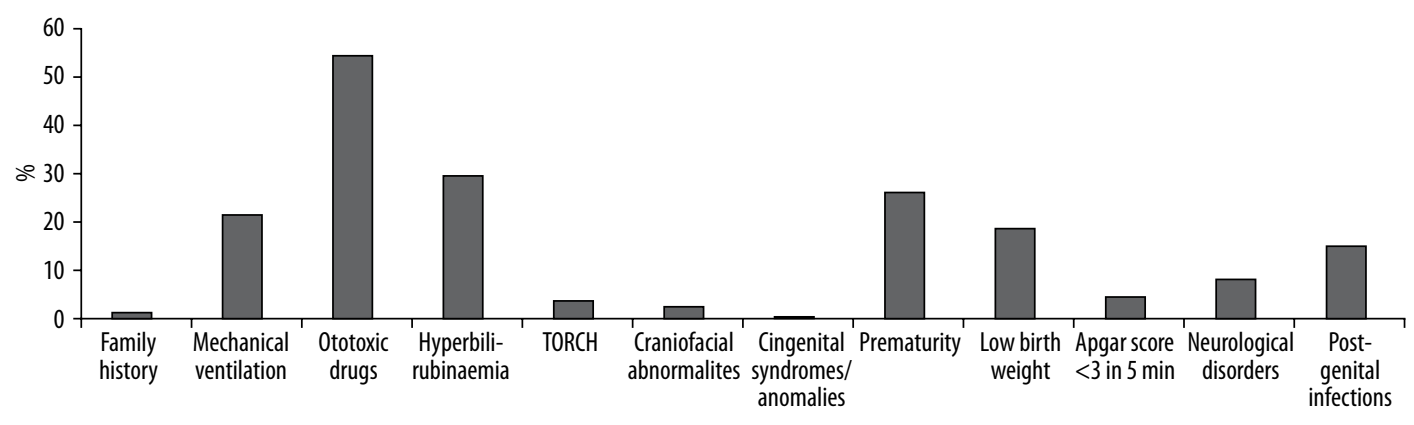

Figure 2. Prevalence of risk factors in the study population

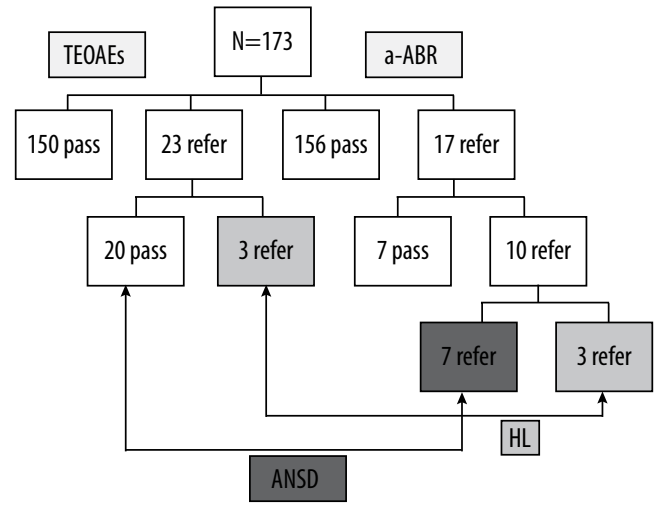

Figure 3. Outcomes of hearing screening of 173 infants from the neonatal intensive care unit. (TEOAEs: transient evoked otoacoustic emissions; aABR: automated auditory brainstem responses; ANSD: auditory neuropathy spectrum disease; $\mathrm{HL}$ : hearing loss)

USA). Categorical variables were presented as counts and percentages of the corresponding population. Pearson's chi-square test was used to compare categorical variables between groups. Comparison of continuous variables between groups was performed using either a $t$-test or an ANOVA Wilcoxon rank-sum tests. A $p$-value $<0.05$ was considered a statistically significant difference.

\section{Results}

The present study included 173 newborns hospitalized at the NICU of our hospital. All neonates met the inclusion criteria, specifically, one or more risk factors for hearing
With regard to TEOAEs examination, 150 (86.7\%) newborns passed the test (PASS) on both ears, whereas 23 (13.3\%) neonates failed the test (REFER) on at least one ear (Figure 3). Pre-discharge, these 23 infants were re-examined for presence of TEOAE. Only 3 of them failed the test again; 1 was bilateral and 2 were unilateral. The false REFER result was $11.6 \%$ of the overall population.

All neonates were also examined with a-ABR. The results revealed that 156 infants $(90.2 \%)$ passed the test and 17 $(9.8 \%)$ failed. The latter group was re-tested before discharge from the NICU; 7 of them passed, whereas 10 (5.8\% of the screened population) failed also at the second test. Some $70 \%$ percent of those who eventually failed a-ABR ( $4 \%$ of the overall population) passed TEOAE and were diagnosed as having possible auditory neuropathy spectrum disease (ANSD). The rest who failed both TEOAE and a-ABR ( $1.7 \%$ of the overall population) were diagnosed as having possible hearing loss (HL). Out of 7 with possible ANSD, 2 neonates failed the a-ABR unilaterally and 5 bilaterally. On the other hand, 1 infant presented with bilateral and 2 neonates with unilateral possible HL.

Risk factor analysis according to the final results of both TEOAEs and a-ABRs is set out in Table 1. These data indicate that in our sample, from the risk factors proposed by the Joint Committee of Infant Hearing, the most significant risk factor reaching statistical significance was TORCH infections, clearly related to the likelihood of hearing impairment, either ANSD or HL $(p=0.004)$. Specifically, there was a trend for more frequent TORCH infections in neonates with possible ANSD (14.3\% vs. $2.5 \%$ with normal results, $p=0.07$ ), and a statistically significant difference among newborns who passed and those who failed both tests $(2.5 \%$ vs. $33.3 \%$, respectively, $p=0.002)$. 
Table 1. Comparison of risk factors between normal hearing infants, possible ANSD, and possible $\mathrm{HL}$

\begin{tabular}{|c|c|c|c|c|c|c|c|}
\hline \multirow{2}{*}{$\begin{array}{l}\text { Risk factor } \\
\text { Family history of childhood deafness }\end{array}$} & \multicolumn{2}{|c|}{ *NH(\%) [N=163] } & \multicolumn{2}{|c|}{${ }^{* \star}$ ANSD (\%) [N=7] } & \multicolumn{2}{|c|}{${ }^{* * *} \mathrm{HL}(\%)[\mathrm{N}=3]$} & \multirow{2}{*}{$\frac{\mathbf{P}}{0.970}$} \\
\hline & 1 & $(0.6)$ & 0 & & 0 & & \\
\hline Mechanical ventilation & 30 & $(18.4)$ & 1 & $(14.3)$ & 2 & $(66.7)$ & 0.103 \\
\hline Ototoxic drugs & 91 & $(55.8)$ & 4 & $(57.1)$ & 0 & & 0.155 \\
\hline $\begin{array}{l}\text { Hyperbilirubinemia } \\
>17 \mathrm{mg} / \mathrm{dl}\end{array}$ & 41 & $(25.2)$ & 2 & $(28.6)$ & 2 & $(66.7)$ & 0.264 \\
\hline TORCH infections & 4 & $(2.5)$ & 1 & $(14.3)$ & 1 & (33.3) & 0.004 \\
\hline Craniofacial abnormalities & 3 & $(1.8)$ & 0 & & 0 & & 0.911 \\
\hline Congenital anomalies or syndromes & 0 & & 0 & & 0 & & NS \\
\hline Prematurity $\leq 32$ weeks & 36 & $(22.1)$ & 1 & $(14.3)$ & 1 & $(33.3)$ & 0.791 \\
\hline Birth weight $\leq 1500 \mathrm{~g}$ & 27 & $(16.6)$ & 1 & $(14.3)$ & 1 & $(33.3)$ & 0.731 \\
\hline Apgar score $<3$ in 5 min & 6 & $(3.7)$ & 0 & & 0 & & 0.826 \\
\hline Neurological disorders & 11 & (6.7) & 1 & $(14.3)$ & 0 & & 0.664 \\
\hline • convulsions & 4 & $(2.5)$ & 1 & $(14.3)$ & 0 & & 0.179 \\
\hline Post-genital infections & 26 & $(16.0)$ & 1 & $(14.3)$ & 0 & & 0.749 \\
\hline
\end{tabular}

* $\mathrm{NH}$ - normal hearing; ${ }^{* *}$ ANSD - auditory neuropathy spectrum disease; ${ }^{* * *} \mathrm{HL}-$ hearing loss.

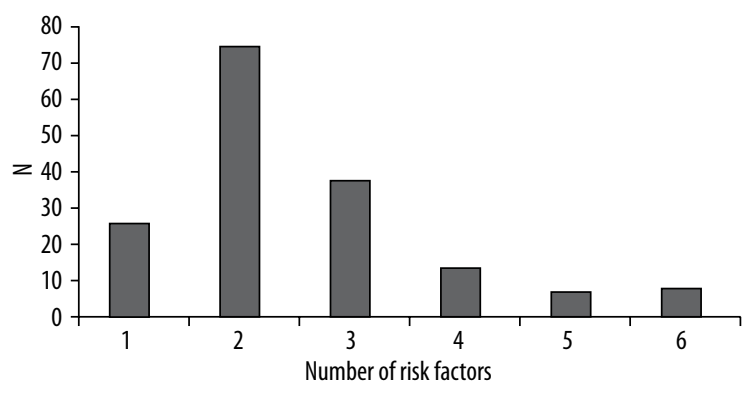

Figure 4. Frequency of occurrence of multiple risk factors

The percentage of infants who needed mechanical ventilation for more than 5 days was also significantly higher in newborns with possible HL, compared to those with normal results $(66.7 \%$ vs. $18.4 \%, p=0.03)$.

There was no statistically significant difference among the three groups with regard to sex, family history of deafness, mechanical ventilation for more than 5 days, administration of ototoxic medication, high levels of bilirubin $(>17 \mathrm{mg} / \mathrm{dL})$, craniofacial abnormalities, prematurity ( $\leq 32$ weeks), low birth weight $(\leq 1500 \mathrm{~g})$, low Apgar score ( $<3$ at $5 \mathrm{~min}$ ), post-genital infections, and neurological disorders. Interestingly, convulsions were more frequent in infants with possible ANSD compared to the rest of the screened population ( $14.3 \% v s$. $2.5 \%$, respectively, $p=0.07)$. Ototoxic drug administration was the most frequent risk factor in neonates with possible ANSD (57.1\%).

The number of coexisting risk factors for the overall population is depicted in Figure 4. All neonates had at least one risk indicator, which was hospitalization in NICU for more than 5 days. The majority of infants had two or three risk factors for hearing impairment $(42.2 \%$ and $20.2 \%$, respectively). No neonate had more than six risk factors. Most of newborns with possible diagnosis of auditory neuropathy spectrum disease experienced two risk factors for hearing loss $(42.9 \%)$. Coexisting risk factors had no additive value as risk indicator for possible hearing impairment, either ANSD or HL $(F=0.444, p=0.817)$.

\section{Discussion}

Hearing impairment in children is a very frequent condition, 20 times more prevalent in newborns than other disorders such as hypothyroidism, phenylketonuria, or anemia, which are usually tested in routine screening protocols. The impact of hearing loss has been associated with delays in speech, language, and social and emotional development $[10,11]$. Over recent decades a lot of work has been done in early diagnosis and intervention, and it has been shown that early application of appropriate intervention can reduce or even eliminate the gap in development between children with normal hearing and those with hearing loss $[12,13]$. The discovery of OAEs by Kemp in 1978 marked a new era in the field of hearing screening. OAEs can determine cochlear status, specifically outer hair cell function, from the first day after birth. As this test is safe, quick, and reliable, it now comprises the core of all screening programs worldwide.

In 1994 the American Academy of Pediatrics Task Force on Newborn and Infant Hearing recommended that all neonates should be tested for hearing impairment and this examination should be part of a general hearing screening program. This position statement was revised and updated in 1999 and 2007. Nowadays, the JCIH supports early detection and intervention for infants with hearing loss. The 
main guideline is that all newborns should be screened during the first month after birth, and those who do not pass screening should have a comprehensive audiological evaluation until the $3^{\text {rd }}$ month of age. Those neonates who have been diagnosed with hearing impairment should receive appropriate intervention within 6 months of birth. The JCIH recommends different protocols for NICU and well-infant nurseries. This is due to the fact that the risk of hearing loss is 10 to 20 times higher in an NICU than in the general population [14]. Infants hospitalized in NICU are also at higher risk for auditory neuropathy/dyssynchrony, a condition that might be missed using only a screening protocol with OAEs. Auditory neuropathy spectrum disorder is found in patients of all ages and is characterized by normal outer hair cell function and abnormal/dyssychrony or absent inner hair cells/neural function. Therefore, a combination of otoacoustic emissions and auditory brainstem responses is recommended [15]. ABRs rely on the synchronous discharge of neural units in the auditory pathways from the inner hair cells $/ 8^{\text {th }}$ nerve through the auditory pathway in the brainstem. ANSD still remains a new clinical entity with little evidence of its etiology, incidence, or treatment [16]. Both tests are more reliable when performed during natural sleep in a quiet environment, because they might be influenced by motion artifacts. Moreover, the combination of TEOAEs and a-ABRs results in low false referral rates.

Although risk factors for hearing loss have been used for screening newborns in many countries worldwide, these factors are constantly updated by the JCIH, due to the fact that their effect may vary in different countries or time periods. For example, in developed countries risk factors for hearing impairment might be decreased due to advanced medical care. More infants with severe birth complications survive, while ototoxic agents are now used for short periods of time with regular assessments of drug blood levels. Therefore, it is very important to investigate consecutively these factors and modify them according to clinical practice. In our study, ototoxic medication was the most frequent risk factor, followed by hyperbilirubinaemia, prematurity, mechanical ventilation, low birth-weight, and post-genital infections. These factors were the most frequently observed in high risk infants for HL; also in other trials with predominance of low birth-weight, prematurity, and ototoxic drug administration [17-19]. However, the frequent existence of a specific risk factor does not necessarily mean that this factor has any causative effect to the outcomes of screening.

With TEOAEs, the referral rate in our study after the twostep protocol was approximately $2 \%$, similar to other studies on universal screenings with TEOAE protocols [20]. Our study protocol included also an a-ABR which was conducted independently on all neonates in the NICU. This examination had a $5.8 \%$ referral rate in the screened population. This percentage may rise up to $12 \%$ in studies that perform ABR as a third step [21]. By comparing the final results of the two examinations, we found that $4 \%$ of the overall population failed a-ABR and passed TEOAE (at least unilaterally). These neonates were diagnosed as having possible auditory neuropathy spectrum disease (ANSD). The prevalence of ANSD in neonates hospitalized in NICU has been estimated at approximately $2 \%$; however this rate can increase up to $11 \%$ in newborns with confirmed diagnosis of permanent HL [22-24]. Neonates who failed both TEOAE and a-ABR (1.7\% of the screened population) were diagnosed as having possible hearing loss (HL). Although this is not a definite diagnosis - and this fact seems to be a weakness of the study - further indepth examination of the failed newborns is beyond the scope of the present study which focuses only on the outcomes of the screening protocols.

Comparison of frequencies of risk factors among the three groups (normal hearing, ANSD, HL) revealed that TORCH infections were significantly correlated with the likelihood of hearing impairment. One-third of infants with possible diagnosis of $\mathrm{HL}$, and $15 \%$ of those with possible diagnosis of ANSD, experienced a TORCH infection. Convulsions were also more frequently observed in the latter group. In other studies screening infants at risk, TORCH infections and neurological disorders have also been identified as risk factors associated with ANSD [18,25]. Family history of childhood deafness, craniofacial abnormalities, congenital anomalies or syndromes, and bacterial meningitis had too low or nilpotent prevalence for statistical analysis. Of course, not finding an association does not mean that this association does not exist, as small numbers may have influenced the related statistical analysis.

Furthermore, mechanical ventilation for more than 5 days was significantly related with the likelihood of HL diagnosis. This risk factor, along with severe birth asphyxia, was described as an independent risk indicator for hearing loss in a recent study conducted in NICU infants [20]. The functional unit of the inner hair cell is vulnerable to mild hypoxia, while the outer hair cells appear more resistant. This finding is consistent with a pattern of auditory neuropathy. In our study, ototoxic drug administration was the most frequent risk factor in neonates with possible ANSD (57.1\%). These drugs included mostly aminoglycosides, in combination or not with loop diuretics. Although in a recent case control study performed at an NICU, where vancomycin administration was the risk factor most significantly associated with auditory neuropathy spectrum disorder, we did not find a statistically significant association with ANSD, probably due to the short time of its administration and close monitoring of ototoxic drug serum levels [26].

Hyperbilirubinaemia seems to be a risk factor for hearing impairment. This observation may be explained by the selective deposition of bilirubin in the brainstem nuclei of the vestibulocochlear pathway and spiral ganglion containing cell bodies of the primary auditory neurons $[19,27,28]$. In the screened population, almost one-third with possible ANSD, and two-thirds with possible HL, experienced hyperbilirubinaemia ( $>17 \mathrm{mg} / \mathrm{dL})$ and required either phototherapy and/or exchange transfusion. Prematurity and low birth-weight were not found to differ significantly among groups, probably owing to the high prevalence of premature births in the general population. This finding has been also described in other studies, and in many of them the population recruited included only premature neonates in order to accentuate the other risk factors.

The presence of coexisting risk factors in a neonate is quite common. Some $73 \%$ of the screened population had two risk factors, $35 \%$ had three, and 39\% had at least four risk factors. Although coexistence of risk indicators appears 
to be an additional risk factor for hearing impairment in some studies $[7,18]$, this finding was not found in the present study, as also in other trials.

As mentioned before, one weakness in the present study, as in many related studies, is the relatively small number of NICU neonates and the large number of risk factors for hearing loss, making it difficult to reach statistical significance. Perhaps in the future a metanalysis or a large multi-centre study might address this issue.

\section{Conclusions}

It seems that both TEOAEs and a-ABRs are mandatory as a screening protocol in NICU neonates. It is well known that high-risk infants have a higher incidence of hearing loss, especially for auditory neuropathy spectrum disorders. Although this is a challenging disorder, since many factors involved in its pathogenesis and etiology are still unclear, a combination of both tests remains the appropriate choice in order to diagnose this condition. The referral rates $(2-6 \%)$ in the present study are acceptable and may be attributed to the repetition of testing and the conjunction of the two tests.

\section{Acknowledgements}

The authors express their gratitude to the doctors and staff of the neonatal intensive care unit of Attiko University Hospital.

\section{References:}

1. Erenberg A, Lemons J, Sia C, Trunkel D, Ziring P. American Academy of Pediatrics, Newborn and Infant Hearing loss, Detection and Intervention Task Force on Newborn and Infant Hearing. Pediatrics, 1999; 103: 527-30.

2. Downs MP, Yoshinaga-Itano C. The efficacy of early identification and intervention for children with hearing impairment. Pediatr Clin North Am, 1999; 46: 79-87.

3. Yoshinaga-Itano C, Sedey AL, Coulter DK, Mehl AL. Language of early and later identified children with hearing loss. Pediatrics, 1998; 102: 1161-71.

4. American Academy of Pediatrics Joint Committee on Infant Hearing 1994 Position Statement. Pediatrics, 1995; 95: 152-6.

5. Geelhoed EA, Lewis B, Hounsome D, O'leary P. Economic evaluation of neonatal screening for phenylketonuria and congenital hypothyroidism. J Paediatr Child Health, 2005; 41(11): $575-9$.

6. Joint Committee on Infant Hearing; American Academy of Audiology; American Academy of Pediatrics; American Speech - Language - Hearing Association; Directors of Speech and Hearing Programs in State Health and Welfare Agencies. Year 2000 Position Statement: Principles and Guidelines for Early Hearing Detection and Intervention Programs. Pediatrics, 2000; 106: 798-817.

7. Martines F, Salvago P, Bentivenga D, Bartolone A, Dispenza F, Martines E. Audiologic profile of infants at risk: experience of a Western Sicily tertiary care centre. Int J Pediatr Otorhinolaryngol, 2012; 76(9): 1285-91.

8. Guidelines Development Conference on the Identification and Management of Infants with Auditory Neuropathy, International Newborn Hearing Screening Conference, Como, Italy, 2008.

9. Joint Committee on Infant Hearing; American Academy of Audiology; American Academy of Pediatrics; American Speech - Language - Hearing Association; Directors of Speech and Hearing Programs in State Health and Welfare Agencies. Year 2007 Position Statement: Principles and Guidelines for Early Hearing Detection and Intervention Programs. Pediatrics, 2007; 120: 898-21.

10. Hehar SS, Nikolopoulos TP, Gibbin KP, O’ Donoghue GM. Surgery and functional outcomes in deaf children receiving cochlear implants before age 2 years. Arch Otolaryngol Head Neck Surg, 2002; 128: 11-4.

11. Nikolopoulos TP, O' Donoghue GM, Archbold SM. Age at implantation: its importance in pediatric cochlear implantation. Laryngoscope, 1999; 109: 595-9.
12. O' Neill C, O'Donoghue GM, Archbold SM, Nikolopoulos TP, Sach T. Variations in gains in auditory performance from pediatric cochlear implantation. Otol Neurotol, 2002; 23: 44-8.

13. Nikolopoulos TP, Gibbin KP, Dyar D. Predicting speech perception outcomes following cochlear implantation using Nottingham children's implant profile (NChIP). Int J Pediatr Otorhinolatyngol, 2004; 68: 137-41.

14. White KR, Vohr BR, Behrens TR. Universal newborn hearing screening using transient evoked otoacoustic emissions: results of the Rhode Island Hearing Assessment Project. Semin Hear, 1993; 14: 18-29.

15. Papacharalampous GX, Nikolopoulos TP, Davilis DI, Xenellis IE, Korres SG. Universal newborn hearing screening, a revolutionary diagnosis of deafness: real benefits and limitations. Eur Arch Otorhinolaryngol, 2011; 268: 1399-406.

16. Mittal R, Ramesh AV, Panwar SS, Nilkanthan A, Nair S, Mehra PR. Auditory neuropathy spectrum disorder: its prevalence and audiological characteristics in an Indian tertiary care hospital. Int J Pediatr Otorhinolaryngol, 2012; 76(9): 1351-4.

17. Biswas AK, Goswami SC, Baruah DK, Tripathy R. The potential risk factors and the identification of hearing loss in infants. Indian J Otolaryngol Head Neck Surg, 2012; 64(3): 214-7.

18. Ohl C, Dornier L, Czajka C, Chobaut JC, Tavernier L. Newborn hearing screening on infants at risk. Int J Pediatr Otorhinolaryngol, 2009; 73: 1691-5.

19. Bielecki I, Horbulewicz A, Wolan T. Prevalence and risk factors for auditory neuropathy spectrum disorder in a screened newborn population at risk for hearing loss. Int J Pediatr Otorhinolaryngol, 2012; 76: 1668-70.

20. Hille ET, van Straaten HI, Verkerk H. Prevalence and independent risk factors for hearing loss in NICU infants. Dutch NICU Neonatal Hearing Screening Working Group. Acta Paediatr, 2007; 96(8): 1155-8.

21. Korres S, Nikolopoulos TP, Komkotou V, Balatsouras D. Newborn hearing screening: effectiveness, importance of high risk factors, and characteristics of infants in the neonatal intensive care unit and well baby nursery. Otol Neurotol, 2005; 26: 1186-90.

22. Sininger Y. Identification of auditory neuropathy in infants and children. Senim. Hear, 2002; 23(3): 193-200.

23. Foerst A, Beutner D, Lang-Roth R, Huttenbrink KB, von Wedel $\mathrm{H}$, Walger M. Prevalence of auditory neuropathy/synaptopathy in a population of children with profound hearing loss. Int J Pediatr Otorhinolaryngol, 2006; 70(8): 1415-22. 
24. Rance G. Auditory neuropathy/dys-synchrony and its perceptual consequences. Trents Amplif, 2005; 9(1): 1-43.

25. Coenraad S, Goedegebure A, van Goudoever JB, Hoeve LJ. Risk factors for auditory neuropathy spectrum disorder in NICU infants compared to normal hearing NICU controls. Laryngoscope, 2011; 121: 852-5.

26. Dowley AC, Whitehouse W, Mason SM, Cope Y, Grant J, Gibbin KP. Auditory neuropathy: unexpectedly common in a screened newborn population. Dev Med Child Neurol, 2009; 51: $642-6$
27. Xionis K, Weirather Y, Mavoori H, Shaha SH, Iwamoto LM. Extremely low birth weight infants are at high risk for auditory neuropathy. J Perinatol, 2007; 27: 718-23.

28. Vlastarakos PV, Nikolopoulos TP, Tavoulari E, Papacharalambous G, Korres S. Auditory neuropathy: endocochlear lesion or temporal processing impairment? Implications for diagnosis and management. Int J Pediatr Otorhinolaryngol, 2008; 72: 1135-50. 